\title{
Mediastinal biopsy for indeterminate chest lesions
}

\author{
STEBBINS B. CHANDOR, EDWARDA. STEMMER, JAMES W. \\ CALVIN, AND JOHN E. CONNOLLY
}

From the Department of Surgery, University of California College of Medicine, Los Angeles, and the Veterans Administration Hospitals, Palo Alto and Long Beach, California

The current literature contains numerous reports on the importance of the mediastinal lymph nodes in the diagnosis and prognosis of pulmonary neoplasms. We recently described a technique by which the mediastinal contents could be explored directly with little risk (Stemmer, Calvin, Chandor, and Connolly, 1965).

Figure 1 illustrates the operative technique. An oblique incision is made just lateral to the sternum and over the second and third costal cartilages. These cartilages are resected subperiosteally. The anterior mediastinum can then be entered without opening the pleura.

When the procedure is carried out on the right side, the innominate vein, superior vena cava, ascending aorta, and the upper portion of the pericardium are exposed by additional sharp and blunt dissection through the anterior mediastinal fat (Fig. 1c). A plane is developed between the ascending aorta and the superior vena cava (Fig. 2 ), which is then retracted laterally to expose the trachea and right pulmonary vessels and provide access to the subcarinal areas (Figs $1 \mathrm{~d}$ and 3 ). If the surgeon wishes, the hilar structures can be dissected for a surprising distance peripherally without producing a pneumothorax. Any lymph nodes or tumour masses in this area are biopsied and the specimens are sent for frozen section. From this point the dissection can be carried into the posterior mediastinum, where a short segment of the oesophagus can be explored visually and needle biopsies of the vertebral bodies obtained as indicated. This procedure is, of course, terminated when the information being sought is obtained. When the procedure is performed on the left side, the dissection is carried out in a similar way, except that it may be difficult or impractical to expose the subcarinal region because of the intervening aortic arch. Mediastinal and hilar masses presenting on the left side radiographically are easily accessible.

Table I summarizes our results with this technique of mediastinal biopsy. Although originally
T A B L E I

SUMMARY OF EXPERIENCE WITH MEDIASTINAL BIOPSY

\begin{tabular}{|c|c|c|c|}
\hline $\begin{array}{c}\text { Final Histological } \\
\text { Diagnosis }\end{array}$ & $\begin{array}{l}\text { Total No. } \\
\text { of Patients }\end{array}$ & $\begin{array}{c}\text { No. of } \\
\text { Positive } \\
\text { Mediastinal } \\
\text { Biopsies }\end{array}$ & $\begin{array}{c}\text { Diagnosis } \\
\text { known } \\
\text { Prior to } \\
\text { Biopsy }\end{array}$ \\
\hline $\begin{array}{ll}\text { Carcinoma lung } & \ldots \\
\text { Lipoid pneumonia } & \ldots \\
\text { Solitary myeloma } & \ldots \\
\text { Bronchiectasis } & \ldots \\
\text { Extrathoracic primaries } \\
\text { Kidney } \\
\text { Thyroid }\end{array} \begin{array}{ll}. & \ldots \\
\text { Hilar adenopathy second- } \\
\text { ary to pneumonia }\end{array}$ & $\begin{array}{r}16 \\
1 \\
1 \\
1 \\
1 \\
1 \\
1\end{array}$ & $\begin{array}{r}13 \\
1 \\
1 \\
0 \\
1 \\
1 \\
0\end{array}$ & $\begin{array}{l}5 \\
0 \\
0 \\
0 \\
0 \\
0 \\
0\end{array}$ \\
\hline Total .. & 22 & 17 & 5 \\
\hline
\end{tabular}

the technique was used to determine resectability in poor-risk patients with carcinoma of the lung, as our experience accumulated it became apparent that this procedure might also be useful in other situations if the mediastinal dissection could provide information not readily obtainable by more conventional methods. The value of this information would depend on the extent to which the mediastinal tissue would correctly reflect the nature and course of the disease under investigation.

To gain a better understanding of the role and scope of mediastinal biopsy, we undertook studies to correlate pathological changes in the mediastinal lymph nodes with the presence and clinical course of intrathoracic disease processes. First we reviewed the post-operative course of those patients at the Palo Alto Veterans Administration Hospital who had been operated upon for intrathoracic neoplasms. Secondly, we reviewed a necropsy series in which the regional thoracic and cervical lymph nodes had been removed and examined for pathological changes related to coexistent pulmonary disease. Both studies sought to answer the following questions:

1. How often do the conventional methods of investigation prior to thoracotomy fail to yield a tissue diagnosis pre-operatively? 


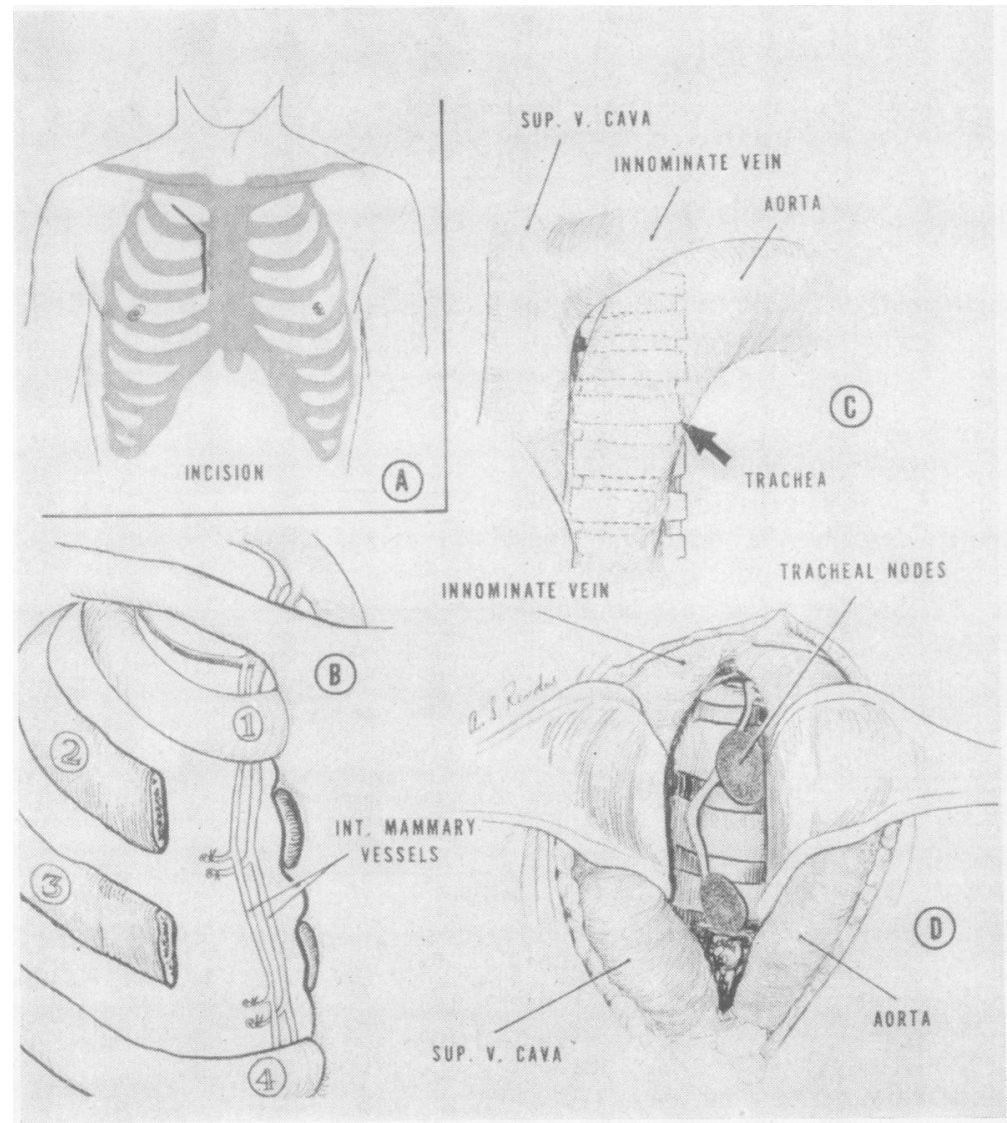

FIG. 1. Diagrammatic illustration of the technique of mediastinal biopsy and the structures encountered during the dissection. A, Location of skin incision. B, Resection of costal cartilages. C, Structures encountered from the right-sided approach. D, Retraction of the aorta and vena cava to expose the pretracheal nodes and trachea.

2. How often would biopsy of the mediastinal tissues provide this information?

3. How does the screening value of mediastinal biopsy compare with that of scalene node dissection?

4. Can biopsy of the mediastinal tissues detect those patients whose disease will be unresectable at formal thoracotomy?

5. How often would the recovery of positive mediastinal tissue label a patient as unresectable when, in fact, the intrathoracic disease could have been successfully resected?

6. How often do the morphological changes found in the mediastinal nodes and tissues correlate with the primary disease?
FAILURE TO OBTAIN A TISSUE DIAGNOSIS

To answer the first question we reviewed the case histories of all patients at the Palo Alto $\mathscr{N}$ Veterans Administration Hospital in whom a diagnosis of carcinoma of the lung had been made. In the four-year period from 1960 to 1964 there was a total of 123 such patients. All were white men between the ages of 38 and 86 years, and $50 \%$ were in the fifth and sixth decades. All but one were smokers and over $50 \%$ had smoked more than 70 pack $^{1}$ years. The types of tumours seen were as follows: adenocarcinoma 47, epidermoid 37 , oat cell 21 , mixed 7 , and undifferen-

${ }^{1}$ A pack contains 20 cigarettes 


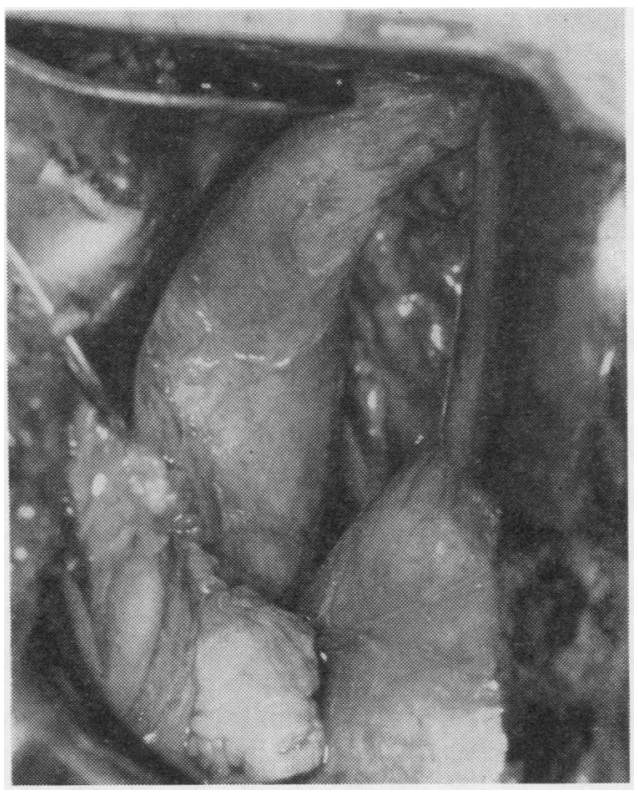

FIG. 2. Corresponds to Fig. $1 D$ and shows the innominate vein crossing (top of photograph) to join the superior vena cava (centre). A retractor displaces the ascending aorta to the right of the illustration. The pretracheal areolar tissue is seen posteriorly between the superior vena cava and the ascending aorta.

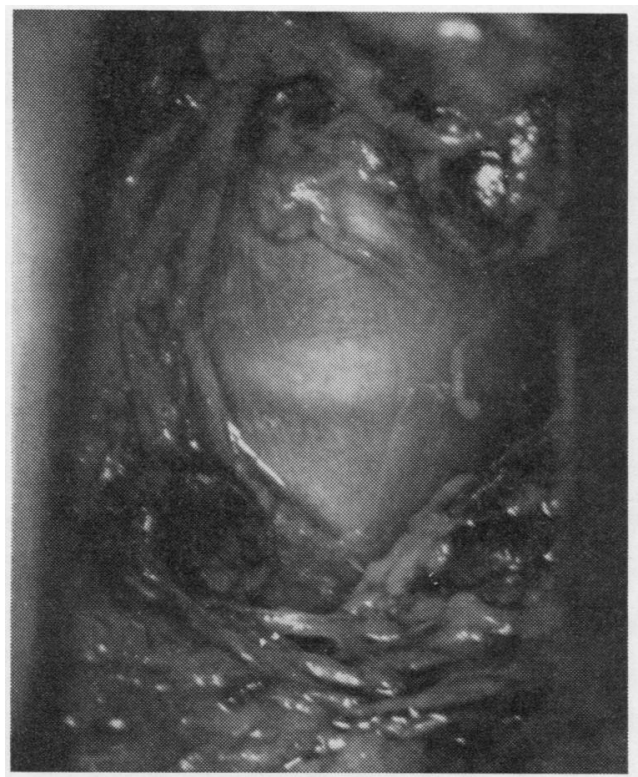

FIG. 3. Shows the trachea and pretracheal lymph nodes exposed just superior to the tracheal bifurcation.
T A B L E I I

METHOD OF DIAGNOSIS IN 123 PATIENTS WITH CARCINOMA OF THE LUNG

\begin{tabular}{|c|c|c|c|c|}
\hline Procedure & & $\begin{array}{c}\text { No. } \\
\text { Done }\end{array}$ & Positive & $\begin{array}{c}\text { Initial } \\
\text { Diagnosis }\end{array}$ \\
\hline 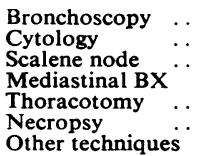 & $\begin{array}{l}\cdots \\
\cdots \\
\cdots \\
\cdots \\
\cdots \\
\cdots\end{array}$ & $\begin{array}{r}82 \\
101 \\
68 \\
16 \\
39 \\
8 \\
9\end{array}$ & $\begin{array}{r}40 \\
35 \\
20 \\
13 \\
39 \\
8 \\
0\end{array}$ & $\begin{array}{r}25 \\
22 \\
18 \\
8 \\
33 \\
8 \\
9\end{array}$ \\
\hline
\end{tabular}

tiated 11. The conventional diagnostic techniques of bronchoscopy, cytology, and scalene node dissection provided an initial tissue diagnosis in $52 \%$ of these patients (Table II). Formal thoracotomy was necessary to obtain a tissue diagnosis in $27 \%$, whilst a diagnosis was obtained at necropsy only in $6 \%$. The initial tissue diagnosis was established by mediastinal biopsy in eight patients. In the remaining nine cases tissue diagnosis was obtained by other techniques such as biopsy of metastatic sites. Of the 33 patients undergoing thoracotomy for diagnosis, $11(33 \%)$ were found to be unresectable. Thus our experience, which corresponds with that of others (Reynders, 1964 ; van der Schaar and van Zanten, 1965), indicates the potential value of an additional diagnostic procedure prior to thoracotomy.

\section{DIAGNOSTIC YIELD OF MEDIASTINAL TISSUES}

To answer the second question we reviewed our first 22 mediastinal biopsies. Each patient had been selected for the procedure because radiological and/or clinical information suggested that the mediastinum was involved by the intrathoracic disease. Scalene node dissection, bronchoscopy, and cytology were carried out prior to mediastinal biopsy in all but one. Of the 16 in whom all three of these diagnostic procedures were negative, 12 were found to have mediastinal nodes positive for the patients' primary disease (8 primary carcinoma of the lung) (Table III).

\section{T A B L E I I I}

INCIDENCE OF POSITIVE MEDIASTINAL BIOPSIES AFTER PRIOR NEGATIVE DIAGNOSTIC WORKUP

\begin{tabular}{ll|l|c|c}
\hline \multirow{2}{*}{ Diagnostic Procedure } & \multicolumn{2}{|c}{ Mediastinal Biopsy } \\
\cline { 3 - 4 } & & & Positive & Negative \\
\hline $\begin{array}{l}\text { Negative } \\
\text { Positive }\end{array}$ & $\ldots$ & $\ldots$ & 12 & 4 \\
& & $\ldots$ & 5 & 2 \\
\hline
\end{tabular}

Although these cases were specially selected as indicated, it is apparent that mediastinal biopsy can provide tissue information not obtainable by the usual diagnostic procedures. Moreover, using 
this technique, 11 of the 12 patients were spared the risks and discomforts of thoracotomy.

\section{COMPARISON OF MEDIASTINAL BIOPSY WITH SCALENE NODE DISSECTION}

The poor correlation between resectability and a prior negative scalene node dissection is well known and has often been commented upon in the literature (Shefts, Terrill, and Swindell, 1953 ; Skinner, Hall, Carr, and Robbins, 1955 ; Scott, 1957 ; Smith, Parsons, and Daniels, 1959 ; Morgan and Scott, 1962). In our own series we found that the mediastinal lymph nodes were frequently positive when the scalene lymph nodes were negative, and that there was a better correlation between positive mediastinal tissue and unresectability than there was between negative scalene lymph nodes and resectability (Tables III and IV). In 60

T A B L E I V

INCIDENCE OF UNRESECTABILITY AFTER VARIOUS DIAGNOSTIC PROCEDURES IN A GROUP OF PATIENTS WITH CARCINOMA OF THE LUNG

\begin{tabular}{c|c|c|c|c}
\hline $\begin{array}{c}\text { Patients } \\
\text { Undergoing }\end{array}$ & $\begin{array}{c}\text { Unresect- } \\
\text { able }\end{array}$ & $\begin{array}{c}\text { Scalene } \\
\text { Biopsy } \\
\text { Positive }\end{array}$ & $\begin{array}{c}\text { Media- } \\
\text { stinal } \\
\text { Biopsy } \\
\text { Positive }\end{array}$ & $\begin{array}{c}\text { Total } \\
\text { No. of } \\
\text { Patients } \\
\text { in Group }\end{array}$ \\
\hline $\begin{array}{l}\text { Thoracotomy } \\
\text { Mediastinal BX }\end{array}$ & 12 & $0^{*}$ & 9 & 39 \\
$\begin{array}{c}\text { Scalene node dis- } \\
\text { section .. }\end{array}$ & 15 & 0 & 12 & 16 \\
\hline
\end{tabular}

* Only patients with negative scalene nodes underwent thoracotomy. + Mediastinal biopsy was not done on all patients in whom a scalene node dissection was performed.

random necropsied patients, of whom 19 had carcinoma, the mediastinal lymph nodes were positive in every case in which the scalene lymph nodes were positive. Following the adoption of mediastinal biopsy in addition to scalene node dissection as a screening procedure, our resectability rate at formal thoracotomy rose from $64 \%$ to $82 \%$. Although neither of these figures is as good as those reported by Reynders (1964), they are in substantial agreement with his findings using a different method of mediastinal exploration before thoracotomy.

\section{DETECTION OF UNRESECTABILITY BY MEDIASTINAL BIOPSY}

The use of mediastinal biopsy to discover those patients with unresectable disease before thoracotomy depends on the frequency with which the tumours have spread to involve the mediastinal structures. To evaluate this we reviewed a series of patients who had undergone thoracotomy for carcinoma of the lung and a series of patients with carcinoma of the lung who came to necropsy without thoracotomy. During the period 1960 to 1964 , a total of 123 patients were seen with carcinoma of the lung. Only 39 of these underwent thoracotomy for 'cure'. Of these, resection was carried out in 27 , while the remaining $12(30 \%)$ were found to be unresectable (Table V). The

T A B L E V

EXPERIENCE WITH 39 CONSECUTIVE THORACOTOMIES

\begin{tabular}{|c|c|c|c|c|c|}
\hline $\begin{array}{l}\text { Total resected } \\
\text { Total unresectable }\end{array}$ & 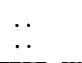 & 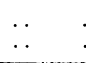 & $\begin{array}{l}\cdots \\
\cdots\end{array}$ & $\begin{array}{l}\cdots \\
\cdots\end{array}$ & $\begin{array}{l}27 \\
12\end{array}$ \\
\hline \multicolumn{4}{|c|}{$\begin{array}{l}\text { Mediastinal extension } \\
\text { Limiting systemic disease }\end{array}$} & $\begin{array}{l}9 \\
1 \\
1 \\
1\end{array}$ & \\
\hline
\end{tabular}

reason for unresectability in nine of these 12 patients was involvement of the mediastinal structures. All could have been detected by mediastinal biopsy. These patients in the second group were inoperable for various reasons other than mediastinal involvement but are included here to demonstrate the frequency that such involvement is part of the picture of inoperability and/or unresectability. There were 42 patients in this category, of whom 38 were found at necropsy to have mediastinal extension that would have been accessible to our procedure. Thus a total of 47 patients with unresectable disease could have been detected by mediastinal biopsy. This experience was borne out by our clinical series of mediastinal biopsies, which included 16 patients who had an unresectable carcinoma of the lung (Table I). Thirteen of these were detected by mediastinal biopsy. These results are in agreement with those of Reynders (1964), who reported an incidence of $86 \%$ in the same situation.

CORRELATION BETWEEN MEDIASTINAL INVOLVEMENT AND UNRESECTABILITY

Even if it is conceded that exploration of the mediastinum can detect those with unresectable malignancies, there remains the question whether or not the mediastinal disease in others could be treated by more radical surgery. Our experience with 34 patients who had mediastinal involvement included none in whom the disease could have been cleared even with radical surgery. Nine of the patients had undergone thoracotomy and were considered to be unresectable. Fifteen of the 34 underwent mediastinal biopsy without subsequent thoracotomy. All these had additional evidence of unresectability (Table IV). The remaining 10 patients were collected from the previously mentioned necropsies. Ten were found to have 
tumour present in the mediastinum as well as in other areas from which it could not have been removed at thoracotomy. Four of these $10 \mathrm{had}$ primary tumours outside the thorax, the other six had primary carcinoma of the lung. If only the lower tracheal and carinal lymph nodes are involved by tumour, the primary along with its metastases can sometimes be removed; but this is unlikely. The prognosis for patients with disease as extensive as this is always worse whether or not resection is carried out (Johnson, 1960; Wilkins and Sweet, 1957 ; Barrie, 1952). In any event, preliminary mediastinal exploration in those patients with apparent central spread enables the surgeon to decide whether formal thoracotomy offers a chance of cure without subjecting the remainder of these patients to a fruitless major procedure.

\section{CORRELATION OF NODAL MORPHOLOGY AND INTRATHORACIC DISEASE}

Lymph nodes from 60 random necropsies were dissected from the scalene and mediastinal surgical fields. Nineteen patients had died with carcinoma, of which six were bronchogenic in origin. Sinus cell hyperplasia, granuloma formation, and scarring appeared in the regional nodes in 58 cases but without relationship to specific, active pulmonary diseases. When tumour was present, its spread to the mediastinal lymph nodes was haphazard. Nodes were always present in the areas accessible to our technique of mediastinal biopsy.

\section{DISCUSSION}

Although surgical excision remains the best treatment for carcinoma of the lung, three-fourths of all patients who have a primary pulmonary neoplasm are seen too late to permit curative resection of their disease. Since the prime reason for inoperability is unresectable involvement of the mediastinum, numerous procedures have been developed to detect this in an effort to spare these patients the mortality and morbidity of a formal thoracotomy. Our procedure is a direct approach to the problem. It is our opinion that the open technique has advantages over other methods, since it permits more extensive exploration of the mediastinum.

While primarily intended as a method of evaluating patients with carcinoma of the lung, mediastinal exploration can also be used to diagnose other diseases. Sarcoidosis, tuberculosis, and lymphoma, which can present as mediastinal masses, can be detected by this method. Many of the diseases of the thorax, however, do not produce specific abnormalities within the regional lymphatics. Changes such as follicular hyperplasia, scarring, and granulomatous reactions frequently occurred in a non-specific fashion in response to both healed and active pulmonary pathology. Because of this we have not assigned any great significance to the abnormalities found at mediastinal exploration unless we were able to demonstrate definite and distinct microscopical findings. A negative investigation does not mean that the procedure was carried out in vain, since it is these patients who have the best chance of a curative resection.

\section{SUMMARY}

Clinical and necropsy data have been presented to support the use of preliminary mediastinal exploration in selected patients. Direct mediastinal exploration can be a useful diagnostic and prognostic tool in those patients for whom curative resection appears unlikely and in whom the more routine techniques of diagnosis have not been successful.

\section{BIBLIOGRAPHY}

Barrie, J. (1952). Primary carcinoma of the bronchus: prognosis following surgical resection. Ann. roy. Coll. Surg. Engl., 10, 165 .

Black, M. M., and Speer, F. D. (1960). Lymph node reactivity in cancer patients. Surg. Gynec. Obstet., 110, 477.

Carlens, E. (1959). Mediastinoscopy: a method for inspection and tissue biopsy in the superior mediastinum. Dis. Chest, 36, 343.

Daniels, A. C. (1949). A method of biopsy useful in diagnosing certain intrathoracic diseases. Ibid., 16, 360.

Gregovie, H. B., Jr., Othersen, H. B., Jr., and Moore, P. M., Jr. (1962). The significance of sarcoid-like lesions in association with malignant neoplasms. Amer. J. Surg., 104, 577.

Harken, D. E., Black, H., Clauss, R., and Farrand, R. E. (1954). A simple cervicomediastinal exploration for tissue diagnosis of intrathoracic disease. New Engl. J. Med., 251, 1041.

Johnson, J. (1960). Cancer of the lung-five-year results. West. J. Surg., 68, 30.

Morgan, S. W., and Scott, S. M. (1962). A critical reappraisal of scalene fat pad biopsies. J. thorac. cardiovasc. Surg., 43, 548 .

Palva, T. (1961). Mediastinoscopy: a new field for bronchologists. Acta oto-laryng. (Stockh.), 53, 578.

Pearson, F. G. (1963). Mediastinoscopy: a method of biopsy in the superior mediastinum. Canad. J. Surg., 6, 423.

Reynders, H. (1964). Mediastinoscopy in bronchogenic cancer. Dis. Chest, 45, 606.

Scott, S. M. (1957). A critical review of 160 consecutive scalene node biopsies. Amer. Rev. Tuberc., 76, 1002.

Shefts, L. M., Terrill, A. A., and Swindell, H. (1953). Scalene node biopsy. Ibid., 68, 505.

Skinner, E. F., Hall, J., Carr, D., and Robbins, S. G. (1955). Routine supraclavicular biopsy in suspected bronchogenic carcinoma, parietal pleura, and lung node. Amer. Surg., 21, 590.

Smith, J. W., Parsons, H. G., and Daniels, A. C. (1959). Scalene biopsy in the diagnosis of intrathoracic disease. J. thorac. Surg., 37, 611 .

Steele, J. R., and Marable, S. A. (1959). Cervical mediastinotomy for biopsy. J. thorac. cardiovasc. Surg., 37, 621.

Stemmer, E. A., Calvin, J. W., Chandor, S. B., and Connolly, J. E. (1965). Mediastinal biopsy for indeterminate pulmonary and mediastinal lesions. Ibid., 49, 405.

Van der Schaar, P. J., and van Zanten, M. E. (1965). Experience with mediastinoscopy. Thorax, 20, 211.

Wilkins, E. W., Jr., and Sweet, R. H. (1957). Carcinoma of the lung. New Engl.'J. Med., 256, 346.

Wolf, P. L., Lewis, B., and McCormick, G. R. (1963). Scalene node 'sarcoidosis'. Arch. intern. Med., 112, 397. 